\title{
Dairy cattle lameness prevalence, causes and risk factors in selected farms of southern Ethiopia
}

\author{
Desie Sheferaw ${ }^{* 1}$, Rahmeto Abebe ${ }^{1}$, Bekele Megersa ${ }^{1}$, Kebede Amenu ${ }^{2}$, Fufa Abunna ${ }^{2}$, \\ Alemayehu Regassa ${ }^{1}$,Yifat Denbarga, Amene Fekadu, Berhanu Mekibib ${ }^{1}$, Eliyas Re- \\ buma $^{1}$, Ephrem Abera ${ }^{1}$, Getnet Sefiw ${ }^{2}$, Debele Hordofa ${ }^{1}$, Amanuel Ashebo ${ }^{1}$ and Firaol \\ $W_{a k o}{ }^{2}$ \\ ${ }^{1}$ Hawassa University, Faculty of Veterinary Medicine, Hawassa, Ethiopia \\ ${ }^{2}$ College of Veterinary Medicine and Agriculture, AAU, Bishoftu, Ethiopia \\ *Corresponding author: Desie Sheferaw, Faculty of Veterinary Medicine, HU, P.O.Box 5, mere- \\ ba480@gmail.com,Mobile: 0916832419.
}

\begin{abstract}
A cross-sectional study was conducted from October 2018 to December 2019 to estimate the prevalence of lameness in dairy cows, to assess the causes and associated risk factors in southern Ethiopia. A total of 2009 dairy cows were visually and clinically examined, and the overall prevalence of lameness was found to be $14.1 \%$ (95\% CI=12.7-15.7). The prevalence of lameness was significantly $(P<0.05)$ higher in Arsi Negelle, Yirgalem, and Wolaita Sodo than in Wondo Genet and Hawassa. The prevalence of lameness was also associated with the stages of pregnancy and parity $(P<0.05)$. Generally, the prevalence of lameness in dairy cows was increasing with the increase in parity and stage of pregnancy. The main abnormalities observed in this study were hooves overgrowth $(6 \%)$, lesions between hooves $(4 \%)$, lesions on legs $(2.2 \%)$, trauma $(0.6 \%)$, arthritis $(0.5 \%)$, and a sole ulcer $(0.3 \%)$. Most of these abnormalities were mainly due to faulty management. Hence, based on this finding it is recommended that hoof management and trimming are very essential components of lameness control. Furthermore, early detection and treatment of lame cows; training of the owners on hoof management; and improvement of the housing are helpful to keep lameness at a lower level.
\end{abstract}

Keywords: Dairy cows; Lameness; Risk factors; Southern Ethiopia. 


\section{Introduction}

Various authors defined lameness differently; however, the sounder definition is "an abnormal gait that is commonly caused by pain" (Whay and Shrear, 2017). It is the most important condition that influences the productivity, health, and welfare of dairy cows. It has a negative effect on milk production (Specher et al., 1997, Green et al., 2002; Hernandez et al., 2002; Bicalho et al., 2007; Keyserlingk et al., 2009; Huxley, 2013; Mandel et al., 2018). Moreover, economic impact of lameness can be attributed to the cost of treatment and controls (Hernandez and Shearer, 2000), increased calving interval, and impaired reproductive performance (Hernandez et al., 2001) and likely increase the risk of culling (Juarez et al., 2003; Cramer et al., 2009; Huxel, 2013). In addition to the economic impact, lameness also affects the behavioral expression of cows due to pain. Indeed, now a day lameness is one of the most important welfare issues in dairy cattle production (Galindo and Broom, 2002; Tremetsberger and Winckler, 2015).

The causes of lameness in dairy cows are often complex and multifactorial (Bell, 2015; Ranjbar et al., 2016), but are generally recognized as poor quality floors in cattle housing, poor cow tracks, and cows being forced to stand for a too long time on hard surfaces, ineffective foot trimming, infectious diseases and poor nutrition.

In Ethiopia, there is a scarcity of information about the prevalence of lameness in dairy cows and the associated risk factors. Therefore, this study aimed to estimate the prevalence, identify the causes of lameness, and assess the potential risk factors involved in the occurrence of lameness in selected dairy farms in southern Ethiopia.

\section{Materials and methods}

\section{Study area}

The study was conducted between October 2018 and March 2019 in Hawassa, Wondo Genet, Yirgalem, Arsi Negelle, and Wolaita Sodo towns (Figure 1). Hawassa, Arsi-Negelle, Yirgalem, Wondo-Genet, and Wolaita Sodo are located at $7^{\circ} 3^{\prime} 43.4^{\prime \prime} \mathrm{N}$ and $38^{\circ} 28^{\prime} 34.9^{\prime \prime} \mathrm{E}, 7^{\circ} 2^{\prime} 59.9^{\prime \prime} \mathrm{N}$ and $38^{\circ} 41^{\prime} 6^{\prime \prime} \mathrm{E}, 6^{\circ} 45^{\prime} \mathrm{N}$ and $38^{\circ} 25^{\prime} \mathrm{E}$, $7^{\circ} 5^{\prime} 3^{\prime \prime} \mathrm{N}$ and $38^{\circ} 37^{\prime} 8^{\prime \prime} \mathrm{E}$, and $6^{\circ} 51^{\prime} 36^{\prime \prime} \mathrm{E}$ and $37^{\circ} 45^{\prime} 41.7^{\prime \prime}$, respectively. The study areas were located at the escarpment of the rift valley, and they are with good 
dairy production potential. The altitudinal range of the study areas is from 1650 (at Hawassa) to 2500 (at Wolaita Sodo and Wondo Genet) meters above sea level (m.a.s.l). The range of annual rainfall was $900-1700 \mathrm{~mm}$ for Hawassa, 500-1100 mm for Arsi Negelle, $1314 \mathrm{~mm}$ for Yirgalem, $1372 \mathrm{~mm}$ for Wondo Genet, and $1446 \mathrm{~mm}$ Wolaita Sodo. The minimum and maximum temperature of Hawassa, Arsi-Negelle, Yirgalem, Wondo-Genet, and Wolaita Sodo were $13^{\circ} \mathrm{C}$ and $25^{\circ} \mathrm{C}, 12.6^{\circ} \mathrm{C}$ and $27.3^{\circ} \mathrm{C}, 14^{\circ} \mathrm{C}$ and $29^{\circ} \mathrm{C}, 9.9^{\circ} \mathrm{C}$ and $29.5^{\circ} \mathrm{C}$, and $15^{\circ} \mathrm{C}$ and $28^{\circ} \mathrm{C}$, respectively (NMA, 2019).

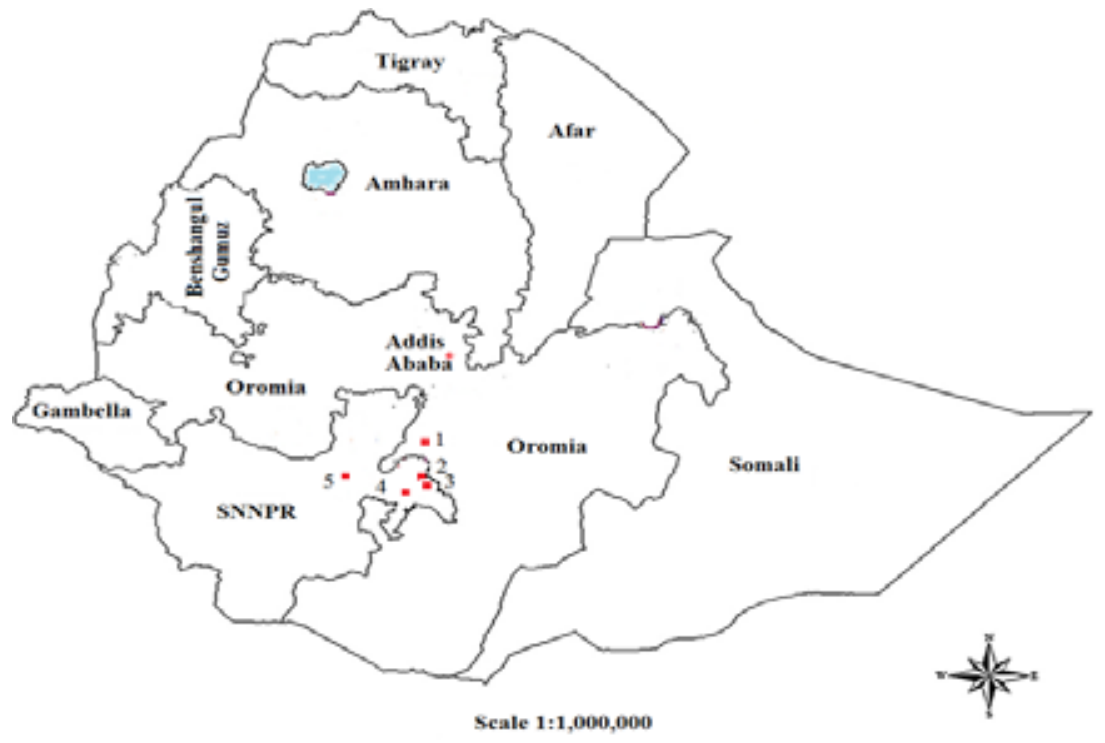

Figure 1. Map of Ethiopia with the regional states and showing the five study areas (1=Arsi Negelle, 2=Wondo Genet, 3=Hawassa, 4=Yirgalem, and 5=Wolaita Sodo)

\section{Study animals and sample size}

Information on dairy cows' lameness was collected from 157 small-scale dairy farms selected from the aforementioned five towns in southern Ethiopia. Farms were purposively selected based on the herd size of 5 or more cows. Based on this criterion, the total number of farms selected was 157. All dairy cows and heifers, at breeding age, found in the selected farms were included in the study. This constituted a total of 2,009 cows and heifers. The number of farms and animals selected from each town was shown in Table 1. 
Table 1.Number of dairy farms and number of cows sampled for the study

\begin{tabular}{lcc}
\hline Name of town & Number of farms selected & Number of animals selected \\
\hline Hawassa & 35 & 789 \\
Yirgalem & 34 & 280 \\
Wondo Genet & 43 & 360 \\
Arsi Negelle & 24 & 168 \\
Wolaita Sodo & 21 & 412 \\
Total & 157 & 2,009 \\
\hline
\end{tabular}

\section{Study design and methodology}

A cross-sectional study was employed to assess the prevalence of dairy cows' lameness. All the animals in the selected farms were carefully observed and clinically examined for lameness. During the visit, the study animals were allowed to move and observed for any symptom of abnormal gait as described by Shearer et al. (2012) and visual locomotion. Those cows with apparent abnormal gait were clinically palpated for reaction and/or pain, observed for the presence of any lesions, shifting of weight on the limbs, and ticks. Potential risk factors for lameness such as herd size, parity, milking status, stage of pregnancy, hoof overgrowth, and study areas were recorded to assess their association with the disease.

\section{Visual locomotion scoring}

All cows in the selected farms were assessed visually for lameness and the gait was scored using a 1- 5 point rating system, where $1=$ normal, $2=$ mild lame, $3=$ moderately lame, 4=lame, and $5=$ severely lame (Flower and Weary, 2006; Chapinal et al., 2009). The observed lameness was characterized as described by Sprecher et al. (1997), Thomsen et al. (2008), and Shearer et al. (2012). According to Sprecher et al. (1997) the definition and classification of cow lameness:

- Normal: Cow stands and walks with a level-back posture, the gait is normal.

- Mild lame: Cow stands with a level-back posture but develops an archedback posture while walking; the gait remains normal.

- Moderately lame: Arched-back posture is evident, both while standing and walking. Cow's gait is affected and is best described as short striding with one or more limbs. 
- Lame: Arched-back posture is always evident and gait is best described as one deliberate step at a time.

- Severely lame: Cow demonstrates an inability or extreme reluctance to bear weight on one or more of the limbs/feet.

\section{Data analysis}

All collected data were entered into Microsoft Excel Spread Sheet, edited and coded, and then, summarized using descriptive statistics like mean. Then, it was analyzed by univariable and multivariable logistic regression analysis to check the association of the aforementioned potential risk factors with the occurrence of lameness. The existences of collinearity among the variable were checked using gamma values (Dohoo et al., 2009). All the statistical analyses were performed on STATA software version 14.2 (STATA Corp, 4905 Lakeway Drive, College Station, Texas 77845 USA). The study considered a 95\% confidence level and $5 \%$ of absolute desired precision.

\section{Results}

\section{Prevalence of clinical lameness}

From a total of 2,009 dairy cows and heifers examined $284(14.1 \%)$ animals were found clinically positive for various degrees of lameness. The prevalence of lameness in each of the study towns is shown in Table 2.

Table 2. Dairy cattle lameness prevalence in the study areas

\begin{tabular}{lcccc}
\hline Study area & No examined & No positive (\%) & Std. Er. & 95\% CI \\
\hline Wondo Genet & 360 & $35(9.7 \%)$ & 0.016 & $7.1-13.2$ \\
Hawassa & 789 & $92(11.7 \%)$ & 0.011 & $9.6-14.1$ \\
Arsi Negelle & 168 & $28(16.7 \%)$ & 0.029 & $11.7-23.1$ \\
Yirgalem & 280 & $50(17.9 \%)$ & 0.023 & $13.8-22.8$ \\
Wolaita Sodo & 412 & $79(19.2 \%)$ & 0.019 & $15.7-23.3$ \\
Overall & 2009 & $284(14.1 \%)$ & 0.008 & $12.7-15.7$ \\
\hline
\end{tabular}

\section{Lameness score}

The locomotion of all the study animals' was recorded during the observation period. All dairy cows and heifers with locomotion scores 2 to 5 were found to 
be lame. Among the animals observed to have lameness (284), 54.6\% $(\mathrm{n}=155)$, $32.7 \%(\mathrm{n}=93), 12 \%(\mathrm{n}=34)$ and $0.7 \%(\mathrm{n}=2)$ were mildly, moderately, lame and severely lame, respectively (Table 3 ).

Table 3. Proportion of locomotion score of dairy cows $(\mathrm{N}=\mathbf{2 0 0 9})$

\begin{tabular}{llcc}
\hline Locomotion score & Description & No examined & Proportion (\%) \\
\hline 1 & Normal (Not lame) & 1,725 & 85.9 \\
2 & Mildly lame & 155 & 7.7 \\
3 & Moderately lame & 93 & 4.6 \\
4 & Lame & 34 & 1.7 \\
5 & Severely lame & 2 & 0.1 \\
Total & & 2009 & 100 \\
\hline
\end{tabular}

\section{Risk factors of lameness}

The result of univariable logistic regression analysis of the prevalence of dairy cows' lameness with various risk factors has been shown in Table 4. Except for the herd size $(P>0.25)$, all the variables considered in the study, that means: study area, parity, milking status, and stage of pregnancy were found significant $(P<0.05)$. All those independent variables, which were significant in the initial univariable analysis checked for co-linearity using Kruskal gamma statistics, and those variables whose gamma value ranged between -0.6 and +0.6 were considered in a multivariable logistic regression model. Accordingly, milking status was excluded from multivariable analysis due to collinearity with parity (gamma $=0.8665$ ). Thus, the variables included in the multivariable model were study area, parity, and pregnancy stage, and all of these variables were found significant $(P<0.05)$ (Table 5$)$. The Hosmer-Lemeshow goodnessof-fit test suggested that the model fit the data $\left(\mathrm{X}^{2}=10.96 ; P=0.1405 ; \mathrm{ROC}=\right.$ $72.1 \%)$. 
Table 4. Univariable logistic regression analysis of risk factors for the occurrence of lameness

\begin{tabular}{|c|c|c|c|c|c|c|}
\hline Risk factors & $\begin{array}{l}\text { Level of } \\
\text { factors }\end{array}$ & $\begin{array}{c}\text { No } \\
\text { examined }\end{array}$ & $\begin{array}{c}\text { No positive } \\
(\%)\end{array}$ & $\begin{array}{l}\text { Std. } \\
\text { Err. }\end{array}$ & $\mathbf{Z}$ & P-value \\
\hline \multirow[t]{5}{*}{ Study areas } & Wondo Genet & 360 & $35(9.7 \%)$ & 0.016 & - & \\
\hline & Hawassa & 789 & $92(11.7 \%)$ & 0.011 & 0.97 & 0.332 \\
\hline & Arsi Negelle & 168 & $28(16.7 \%)$ & 0.029 & 2.27 & 0.023 \\
\hline & Yirgalem & 280 & $50(17.9 \%)$ & 0.023 & 2.97 & 0.003 \\
\hline & Wolaita Sodo & 412 & $79(19.2 \%)$ & 0.019 & 3.67 & 0.000 \\
\hline \multirow[t]{3}{*}{ Parity } & * None & 960 & $56(5.8)$ & - & - & \\
\hline & * $1-3$ & 870 & $182(20.9)$ & 0.014 & 9.02 & 0.000 \\
\hline & $* \geq 4$ & 179 & $46(25.7)$ & 0.033 & 7.83 & 0.000 \\
\hline \multirow[t]{2}{*}{ Milking } & No & 1149 & $67(5.8)$ & - & - & \\
\hline & Yes & 860 & $217(25.2)$ & 0.015 & 11.43 & 0.000 \\
\hline \multirow[t]{4}{*}{ Pregnancy stage } & None & 1543 & $189(12.2)$ & - & - & - \\
\hline & 1st trimester & 276 & $46(16.7)$ & 0.022 & 2.01 & 0.045 \\
\hline & 2nd trimester & 105 & $27(25.7)^{*}$ & 0.043 & 3.84 & 0.000 \\
\hline & 3rd trimester & 85 & $22(25.9)^{*}$ & 0.048 & 3.53 & 0.000 \\
\hline \multirow[t]{3}{*}{ Herd size } & $\leq 9$ & 563 & $75(13.3)$ & 0.014 & & \\
\hline & 10 to 49 & 925 & $132(14.3)$ & 0.012 & 0.51 & 0.608 \\
\hline & $\geq 50$ & 521 & $77(14.8)$ & 0.016 & 0.69 & 0.490 \\
\hline
\end{tabular}


Table 5. Multivariable logistic regression analysis of potential risk factors for lameness in dairy cattle, southern Ethiopia.

\begin{tabular}{|c|c|c|c|c|c|}
\hline Risk factors & $\begin{array}{c}\text { No } \\
\text { examined }\end{array}$ & No positive (\%) & OR & $95 \% \mathrm{CI}$ & P-value \\
\hline \multicolumn{6}{|l|}{ Areas } \\
\hline Wondo Genet & 360 & $35(9.7 \%)$ & - & - & \\
\hline Hawassa & 789 & $92(11.7 \%)$ & 2.71 & $1.19-2.29$ & 0.007 \\
\hline Arsi Negelle & 168 & $28(16.7 \%)$ & 1.98 & $1.01-3.01$ & 0.048 \\
\hline Yirgalem & 280 & $50(17.9 \%)$ & 3.27 & $1.40-3.88$ & 0.001 \\
\hline Wolaita Sodo & 412 & $79(19.2 \%)$ & 5.37 & $2.24-5.65$ & $<0.001$ \\
\hline \multicolumn{6}{|l|}{ Parity } \\
\hline Heifers & 960 & $56(5.8)$ & - & - & \\
\hline $1-3$ & 870 & $182(20.9)$ & 4.06 & $2.92-5.64$ & $<0.001$ \\
\hline$\geq 4$ & 179 & $46(25.7)$ & 6.11 & $3.80-9.82$ & $<0.001$ \\
\hline \multicolumn{6}{|c|}{ Pregnancy stage } \\
\hline None & 1543 & $189(12.2)$ & - & - & \\
\hline $1^{\text {st }}$ trimester & 276 & $46(16.7)$ & 1.34 & $0.92-1.96$ & 0.046 \\
\hline $2^{\text {nd }}$ trimester & 105 & $27(25.7)^{*}$ & 2.65 & $1.60-4.41$ & $<0.001$ \\
\hline $3^{\text {rd }}$ trimester & 85 & $22(25.9)^{*}$ & 2.59 & $1.49-4.51$ & $<0.001$ \\
\hline
\end{tabular}

\section{Abnormalities observed}

During the study period, about eleven different types of abnormalities presumed to be the causes of lameness were observed. Clinically hoof overgrowth was the most commonly identified abnormality followed by lesion between hooves and on the legs (Table 6). 
Table 6. Causes of lameness encountered during the study and their proportion

\begin{tabular}{lcc}
\hline Abnormalities & Frequency & Proportion (\%) \\
\hline Hoof overgrowth & 120 & 42.3 \\
Lesions between hooves & 80 & 28.2 \\
Lesions on legs & 44 & 15.5 \\
Sole ulcer & 6 & 3.3 \\
Arthritis (Carpal and tarsal joint swelling) & 10 & 5.5 \\
Abscess on leg & 2 & 1.1 \\
Trauma and/or bruising on leg & 13 & 7.2 \\
Swelling on leg & 4 & 2.2 \\
Interdigital ticks infestation & 9 & 3.2 \\
Fracture of leg & 6 & 2.1 \\
Faulty injection & 4 & 2.2 \\
Two and more than two abnormalities & 14 & 4.9 \\
\hline
\end{tabular}

\section{Discussion}

The prevalence of lameness in dairy cows recorded in the present study, $14.1 \%$, is comparable to the report from various parts of the world (Gitau et al., 1996; Haskell et al., 2006; Somers et al., 2015; Abunna et al., 2017). However, it is lower than the reports from countries like the UK (Rutherford et al., 2009; Barker et al., 2010; Leach et al., 2010), Czech Republic (Šárová et al., 2011), Turkey(Yaylak et al., 2010), Canada and USA (Von Keyserlingk et al., 2012). In contrast, it is relatively higher than the reports from Sweden (Manske et al., 2002), New Zealand (Fabian et al. 2014), Denmark (Alban, 1995), the USA (Wells et al., 1993), and Ethiopia (Sulayeman and Fromsa, 2012). The variation in the prevalence of lameness between the different areas might be due to the differences in the management system, herd size, seasonal variation, breeds, level of productivity of the cows, and observer's subjectivity (Winckler and Willen, 2001; Channon et al., 2009; Huxley et al., 2012; Van Nuffel et al., 2015; Moreira et al., 2018). A dairy cow managed predominantly indoors will typically experience excessive net hoof growth because growth exceeds wear (Bell et al., 2009). Hoof overgrowth is one of the major causes of lameness as also observed during this study. It was noted that all cows with hoof overgrowth had lameness (Table 6). During the study period, the locomotion of all the cows was observed and scored as described by Sprecher et al. (1997) and Flower and Weary (2006) and the result was shown in Table 3. During this 
study comparatively higher proportion of mild (7.7\%) than moderate $(4.6 \%)$ lameness was observed.

In the multivariable logistic regression analysis, the prevalence of lameness was significantly $(P<0.05)$ associated with the study area, parity, and stage of pregnancy. The odds of lameness in dairy cattle in Hawassa $(\mathrm{OR}=2.71)$, Arsi Negelle $(\mathrm{OR}=1.98)$, Yirgalem $(\mathrm{OR}=3.27)$, and Wolaita Sodo $(\mathrm{OR}=5.37)$ was significantly higher than in Wondo-Genet. During this study, the smallest and highest prevalence was recorded at Wondo Genet and Wolaita Sodo, respectively. These differences might be due to the variation in the management of cows between the two study areas. As observed during the study period in most of the dairy farms in Wolaita Sodo animals were managed indoor, while in Wondo-Genet animals had a certain period for outdoor exercises. The same holds true, i.e. indoor management, for Yirgalem and Arsi-Negelle. It was well documented that animals kept on pasture had a lower prevalence of lameness (Haaskell et al., 2006; Olmos et al., 2009; Adams et al., 2017).

In the present study, the prevalence of lameness in dairy cows increased with an increasing parity number. This is also in agreement with several previous reports around the world (Groehn et al., 1992; Wells et al., 1993; Radostits, 2001; Mohamadnia et al., 2008; Olmos et al., 2009; Yaylak et al., 2010; Solano et al., 2015; Foditsch et al., 2016; Daros et al., 2019). It was noted that the likelihood of lameness was 6.1 and 4.1 times higher in cows with 4 or more parities and in their first to third parity compared to heifers, respectively. According to Solano et al. (2016), the problem of sole ulcer and white line diseases is increasing with parity and perhaps this may be responsible for the higher prevalence of lameness in multiparous cows.

The prevalence of lameness in dairy cows was significantly associated $(P<0.05)$ with the stages of pregnancy. The odds of lameness was significantly higher in pregnant than non-pregnant cows, and there was an increase in the prevalence of lameness with the advancement of pregnancy. The OR was 1.5, 2.7, and 3.6times more in first, second and third pregnancy than non-pregnant, respectively. This is mainly due to the changes in hoof loading with pregnancy, which may predispose the cows' to lameness (Scott, 1988 ; Chapinal et al., 2008).

In the present study, hoof overgrowth (6.2\%) was the major cause of lameness followed by lesions between hooves (4\%), lesions on legs (2.2\%), trauma, and/ or bruising $(0.6 \%)$, and arthritis $(0.5 \%)$. These abnormalities are reported to be 
the cause for cattle lameness by other authors (Radostits, 2001; Huxley et al., 2012; Sulayeman and Fromsa, 2012; Bell, 2015). All cows found lame in this study had overgrown hooves $(n=120,6 \%)$. The association of hoof overgrowth with lameness had also been reported by different authors (Sulayeman and Fromsa, 2012; Solano et al., 2015; Sadiq et al., 2017; Oehm et al., 2019). The sole ulcer is a common report as a cause of lameness in dairy cows (Murray et al., 1996; Radostits, 2001; Barker et al., 2007; Huxley et al., 2012; Sulayeman and Fromsa, 2012; Bicalho and Oikonomou, 2013; Bell, 2015).

\section{Conclusions}

The overall prevalence of dairy cows' lameness in the southern part of Ethiopia was $14.1 \%$. This study revealed that lameness in dairy cows is associated with increasing parity, stage of pregnancy, and management difference among the study sites. The most commonly observed abnormalities in the study animals were hoof overgrowth, arthritis, sole ulcer, interdigital ticks' infestation, and trauma and/or bruising.

Most of the abnormalities observed were due to faulty management, and hence, hoof management and proper trimming is a very essential component of lameness control. Furthermore, detection and treatment of lame cows and training of the farm owners are helpful to keep the prevalence of lameness at a lower level.

\section{Conflict of interest}

The authors declare that there is no conflict of interest

\section{Acknowledgements}

The authors gratefully acknowledge the budget support given by the Research and Technology Transfer Vice President Office of Hawassa University. We also thank the willingness and cooperation of dairy farm owners. 


\section{References}

Abunna, F., Zeben, I., Waketole, H and Mamo, G., 2017. Epidemiology of lameness in extensive and intensive dairy farms in Bishoftu town, central Oromia, Ethiopia. Biomirror, 8(3), 9-17. https://www.researchgate.net/publication/325113066.

Adams, A.E., Lombard, J.E., Fossler, C.P., Román-Muñiz, I.N. and Kopral, C.A., 2017. Associations between housing and management practices and the prevalence of lameness, hock lesions, and thin cows on US dairy operations. J. Dairy Sci., 100(3), 2119-2136. https://doi.org/10.3168/jds.2016-11517

Barker, Z.E., LeachK.A.,Whay, H.R., Bell, N.J. and Main, D.C.J., 2010. Assessment of lameness prevalence and associated risk factors in dairy herds in England and Wales. J. Dairy Sci., 93(3), 932-941. https://doi.org/10.3168/jds.2009-2309.

Bell, N., 2015. The Farm audit: Foot health, lameness, and foot care: In "Bovine medicine” edited by Cockcroft, P.D., $3^{\text {rd }}$ edition, John Wiley and Sons, Ltd., 1606 Golden Aspen Drive, Suites 103 and 104, Ames, Iowa 50010, USA. pp. 406-417.

Bell, N.J., Bell, M.J., Knowles, T.G., Whay, H.R., Main, D.J. and Webster, A.J., 2009. The development, implementation, and testing of a lameness control programme based on HACCP principles and designed for heifers on dairy farms. Vet. J., 180(2), 178-88. doi: 10.1016/j.tvjl.2008.05.020.

Bicalho, R.C., Vokey, F., Erb, H.N. and Guard, C.L., 2007. Visual locomotion scoring in the first seventy days in milk: Impact on pregnancy and survival. J. Dairy Sci., 90(10), 4586-4591. https://doi.org/10.3168/jds.2007-0297.

Bicalho R.C. and Oikonomou, G., 2013. Control and prevention of lameness associated with claw lesions in dairy cows. Livest. Sci., 156(1-3), 96-105. https://doi. org/10.1016/ j.livsci. 2013.06.007.

Channon, A.J., Walker, A.M., Pfau, T., Sheldon, I.M. and Wilson, A.M., 2009. Variability of Manson and Leaver locomotion scores assigned to dairy cows by different observers. Vet. Rec., 164, 388-392. DOI: 10.1136/vr.164.13.388.

Chapinal, N., de Passillé, A.M. and Rushen, J., 2009. Weight distribution and gait in dairy cattle are affected by milking and late pregnancy. J. Dairy Sci., 92(2), 581588. https://doi.org/ 10.3168/jds.2008-1533

Collick, D.W. Ward, W.R. and Dobson, H., 1989. Association between types of lameness and fertility. Vet. Rec., 125, 103-106. DOI: 10.1136/vr.125.5.103

Cramer, G., Lissemore, K.D., Guard, C.L., Leslie, K.E. and Kelton, D.F., 2009. The association between foot lesions and culling risk in Ontario Holstein cows. J. Dairy Sci., 92(6), 2572-2579. https://doi.org/10.3168/jds.2008-1532. 
Daros, R.R., Eriksson, H. K., Weary, D.M. and von Keyserlingk, M.A.G., 2019. Lameness during the dry period: Epidemiology and associated factors. J. Dairy Sci., 102(12), 11414-11427. https://doi.org/10.3168/jds.2019-16741.

Dohoo, I., Martin, W., Stryhn, H., 2009. Veterinary Epidemiologic Research, $2^{\text {nd }}$ edition, Prince Edward Island, AVC, Charlottetown, Pp. 239-249.

Flower, F.C. and Weary, D.M., 2006. Effect of hoof pathologies on subjective assessments of dairy cow gait. J. Dairy Sci., 89(1), 139-146. https://doi.org/10.3168/jds. S0022-0302(06) 72077-X.

Foditsch, C., Oikonomou, G., Machado, V.S., Bicalho, M.L., Ganda, E.K., Lima, S.F., Rossi, R., Ribeiro, B.L., Kussler, A. and Bicalho, R.C., 2016. Lameness prevalence and risk factors in large dairy farms in Upstate New York. Model development for the prediction of claw horn disruption lesions. PLoS ONE, 11(1), e0146718.https:// doi.org/10.1371/journal.pone .0146718.

Galindo, F. and Broom, D.M., 2002. Effects of lameness of dairy cows. J. Appl. Anim. Welf. Sci., 5, 193-201. DOI: 10.1207/S15327604JAWS0503_03.

Gitau, T., McDermontt, J.J. and Mbiuki, S.M., 1996. Prevalence, incidence, and risk factors for lameness in dairy cattle in small-scale farms in Kikuyu Division, Kenya. Prev. Vet. Med., 28(2), 101-115. https://doi.org/10.1016/0167-5877(96)01034-3.

Green, L.E., Hedges, V.J., Schukken, Y.H., Blowey, R.W. and Packington, A.J., 2002. The impact of clinical lameness on the milk yield of dairy cows. J. Dairy Sci., 85(9), 2250-2256. https://doi.org/10.3168/jds.S0022-0302(02)74304-X.

Groehn, J.A., Kaneene, J.B. and Foster, D., 1992. Risk factors associated with lameness in lactating dairy cattle in Michigan. Prev. Vet. Med., 14(1-2), 77-85. https://doi. org/10.1016/ 0167-5877(92)90086-U.

Haskell, M.J., Rennie, L.J., Bowell, V.A., Bell, M.J. and Lawrence, A.B., 2006. Housing system, milk production, and zero-grazing effects on lameness and leg injury in dairy cows . J. Dairy Sci., 89(11), 4259-4266. https://doi.org/10.3168/jds.S00220302(06)72472-9.

Hernandez, J., Shearer, J.K. and Webb, D.W., 2002. Effect of lameness on milk yield in dairy cows. J. Am. Vet. Med. Assoc., 220, 640-644. https://doi.org/10.2460/javma.2002.220.640.

Hernandez, J., Shearer, J.K. and Webb, W.D., 2001. Effect of lameness on the calving-to-conception interval in dairy cows. J. Am. Vet. Med. Assoc., 218, 1611-1614. DOI: 10.2460 /javma.2001.218.1611.

Hernandez, J. and Shearer, J.K., 2000. Efficacy of oxytetracycline for treatment of papillomatous digital dermatitis lesions on various anatomic locations in dairy cows. $J$. Am. Vet. Med.Assoc., 216, 1288-1290. https://doi.org/10.2460/javma.2000.216.1288. 
Hernandez, J., Shearer, J.K. and Elliott, J.B., 1999. Comparison of topical application of oxytetracycline and four nonantibiotic solutions for the treatment of papillomatous digital dermatitis in dairy cows. J. Am. Vet. Med. Assoc., 214(5), 688-690.

Huxley, J.N., 2013. Impact of lameness and claw lesions in cows on health and production. Livest. Sci., 156(1-3), 64-70. https://doi.org/10.1016/j.livsci.2013.06.012.

Huxley, J., Archer, S., Bell, N., Burnell, M., Green, L., Potterton, S., and Reader, J., 2012. Control of Lameness: In dairy herd health, edited by Green, M., Bradley, A., Breen, J., Higgins, H., Hudson, C., Huxley, J., Statham, J., Green, L. and Hayton, A. (Eds), CAB International, Wallingford Oxford Shire OX10 8DE, UK. Pp. 169204.

Juarez, S.T., Robinson, P.H., De Peters, E.J. and Price, E.O., 2003. Impact of lameness on behaviour and productivity of lactating Holstein cows. Appl. Anim. Behav. Sci., 83(1), 1-14. https://doi.org/10.1016/S0168-1591(03)00107-2

Leach, K.A., Whay, H.R., Maggs, C.M., Barker, Z.E., Paul, E.S., Bell, A.K. and Main, D.C.J., 2010. Working towards a reduction in cattle lameness: 1. Understanding barriers to lameness control on dairy farms. Res. Vet. Sci., 89(2), 311-317. https:// doi.org/10.1016/ j.rvsc.2010.02.014.

Mandel, R., Harazy, H., Gygax, L., Nicol, C.J., Ben-David, A., Whay, H.R. and Klement, E., 2018. Detection of lameness in dairy cows using a grooming device. J. Dairy Sci., 101(2), 1511-1517. https://doi.org/10.3168/jds.2017-13207.

Mohamadnia, A.R., Mohamaddoust, M., Shams, N., Kheiri, S.andSharifi, S., 2008. Study on the prevalence of dairy cattle lameness and its effects on production indices in Iran. A locomotion scoring base study. Pak. J. Biol. Sci., 11(7), 1047-50. DOI: 10.3923/pjbs.2008. 1047.1050.

Moreira, T.F., Nicolino, R.R., de Andrade, L.S., Filho, E.J.F. and de Carvalho, A.U., 2018. Prevalence of lameness and hoof lesions in all year-round grazing cattle in Brazil. Trop. Anim. Health Prod., 50, 1829-1834. DOI: https://doi.org/10.1007/ s11250-018-1626-3.

Murray, R.D., Downham, D.Y., Clarkson, M.J., Faull, W.B., Hughes, J.W., Manson, F.J., Merritt, J.B., Russell, W.B., Sutherst, J.E. and Ward, W.R., 1996. Epidemiology of lameness in dairy cattle: description and analysis of foot lesions. Vet. Rec., 138(24), 586-591. DOI: 10.1136/vr.138.24.586.

NMA, 2019. Meteorological Bulletin, http://www.ethiomet.gov.et/data_access/thanks.

O'Callaghan, K., 2002. Lameness and associated pain in cattle-challenging traditional perceptions. In Prac., 24, 214-219. DOI: 10.1136/inprac.24.4.212. 
Oehm, A.W., Knubben-Schweizer, G., Rieger, A., Stoll, A. and Hartnack. S., 2019. A systematic review and meta-analyses of risk factors associated with lameness in dairy cows. BMC Vet. Res., 15, 346. https://doi.org/10.1186/s12917-019-2095-2.

Olmos, G., Boyle, L., Hanlon, A., Patton, J., Murphy, J.J. and Mee, J.F., 2009. Hoof disorders, locomotion ability, and lying times of cubicle-housed compared to pasture-based dairy cows. Livest. Sci., 125(2-3), 199-207. https://doi.org/10.1016/j. livsci.2009.04.009.

Radostits, O.R., 2001. Herd health: Food animal production medicine, $3^{\text {rd }}$ edition, W.B. Saunders Company, Philadelphia. Pp. 492-498.

Ranjbar, S., Rabiee, A.R., Gunn, A. and House, J.K., 2016. Identifying risk factors associated with lameness in pasture-based dairy herds. J. Dairy Sci., 99(9), 7495-7505. https://doi.org/ 10.3168/jds.2016-11142.

Rutherford, K.M.D., Langford, F.M., Jack, M.C., Sherwood, L., Lawrence, A.B. and Haskell, M.J., 2009. Lameness prevalence and risk factors in organic and nonorganic dairy herds in the United Kingdom. Vet. J., 180, 95-105. DOI: 10.1016/j. tvjl.2008.03.015.

Sadiq, M.B., Ramanoon, S.Z., Mansor, R., Syed-Hussain, S.S. and Shaik Mossadeq W.M., 2017. Prevalence of lameness, claw lesions, and associated risk factors in dairy farms in Selangor, Malaysia. Trop. Anim. Health Prod., 49, 1741-1748. DOI: https://doi.org/10.1007/s11250-017-1387-4.

Šárová, R., Stěhulová, I., Kratinová, P., Firla, P. and Špinka, M., 2011. Farm managers underestimate lameness prevalence in Czech dairy herds. Anim. Welf., 20 (2), 201-204.

Scott, G.B., 1988. Lameness and pregnancy in Friesian dairy cows. Br. Vet. J., 144(3), 273-281. https://doi.org/10.1016/0007-1935(88)90114-5.

Shearer, J.K., Van Amstel, S.R. and Brodersen, B.W., 2012. Clinical diagnosis of foot and leg lameness in cattle. Vet. Clin. Food Anim., 28, 535-556. http://dx.doi. org/10.1016/j.cvfa. 2012.07.003.

Shearer, J.K., and Hernandez, J., 2000. Efficacy of two modified nonantibiotic formulations (Victory) for treatment of papillomatous digital dermatitis in dairy cows. $J$. Dairy Sci., 83(4), 741-745. https://doi.org/10.3168/jds.S0022-0302(00)74936-8.

Solano, L., Barkema, H.W., Mason, S., Pajor, E.A., LeBlanc, S.J. and Orsel, K., 2016. Prevalence and distribution of foot lesions in dairy cattle in Alberta, Canada. $J$. Dairy Sci., 99(8), 6828-6841. https://doi.org/10.3168/jds.2016-10941.

Solano, L., Barkema, H.W., Pajor, E.A., Mason, S., LeBlanc, S.J., Heyerhoff,† J.C.Z., Nash, C.G.R., Haley, D.B., Vasseur, E., Pellerin, D., Rushen, J., de Passillé, A.M. and Orsel, K., 2015. Prevalence of lameness and associated risk factors in Ca- 
nadian Holstein-Friesian cows housed in free-stall barns. J. Dairy Sci., 98(10), 6978-6991. https://doi.org/10. 3168/jds.2015-9652.

Somers, J.R., Huxley, J., Lorenz, I., Doherty, M.L. and O’Grady, L., 2015. The effect of lameness before and during the breeding season on fertility in 10 pasture-based Irish dairy herds. Ir. Vet. J., 68, 14. https://doi.org/10.1186/s13620-015-0043-4.

Sprecher, D.J., Hosteler, D.E., Kaneene, J.B., 1997. A lameness scoring system that uses posture and gait to predict dairy cattle reproductive performance. Theriogenology, 47(6), 1179-1187. https://doi.org/10.1016/S0093-691X(97)00098-8.

Sulayeman, M. and Fromsa, A., 2012.Lameness in dairy cattle: Prevalence, risk factors, and impact on milk production. Glob. Vet., 8(1), 01-07.

Thomsen, P.T., Munksgaard, L. and Tegersen, F.A., 2008. Evaluation of a lameness scoring system for dairy cows. J. Dairy Sci., 91(1), 119-126. https://doi.org/10.3168/ jds.2007-0496.

Tremetsberger, L. and Winckler, C., 2015. Effectiveness of animal health and welfare planning in dairy herds: A review. Anim. Welf., 24, 55-67. doi: 10.7120/09627286.24.1.055.

Von Keyserlingk, M.A.G., Rushen, J., de Passille, A.M. and Weary, D.M., 2009. Invited review: The welfare of dairy cattle-Key concepts and the role of science. J. Dairy Sci., 92, 4101-4111. https://doi.org/10.3168/jds.2009-2326.

Van Nuffel, A., Zwertvaegher, I., Pluym, L., Van Weyenberg, S., Thorup, V.M., Pastell, M., Sonck, B. and Saeys, W., 2015. Lameness detection in dairy cows: Part 1. How to distinguish between non-lame and lame cows based on differences in locomotion or behavior. Animals, 5, 838-860. doi: 10.3390/ani5030387.

Warnick, L.D., Janssen, D., Guard, C.L. and Grohn, Y.T., 2001. The effect of lameness on milk production in dairy cows. J. Dairy Sci., 84(5), 1988-1997. https://doi. org/10.3168/jds. S0022-0302(01)74642-5.

Wells, S.J., Trent, A.M., Marsh, W.E. and Robinson, R.A., 1993. Prevalence and severity of lameness in lactating dairy cows in a sample of Minnesota and Wisconsin herds. J. Am. Vet. Med. Assoc., 202(1), 78-82.

Whay, H.R. and Shearer,J.K., 2017. Theimpact of lameness on the welfare of the dairy cow. Vet. Clin. North Am. Food Anim. Pract., 33(2), 153-164. DOI: 10.1016/j. cvfa.2017.02.008.

Winckler, C. and Willen, S., 2001. The reliability and repeatability of a lameness scoring system for use as an indicator of welfare in dairy cattle. Acta Agric. Scand., Sect. A, Animal Sci., Suppl. 51, 103-107. DOI: 10.1080/090647001316923162.

Yaylak, E., Akbas, Y., Kaya, I. and Uzmay, C., 2010. The effects of several cow and herd level factors on lameness in Holstein cows reared in Izmir Province of Turkey. J. Anim. Vet. Adv., 9(21), 2714-2722. DOI: 103923/javaa.2010.2714.2722. 